\title{
A LEGISLAÇÃO ECONÔMICA E SOCIAL CONSE- CUTIVA À PESTE NEGRA DE 1348 E SUA SIGNI- FICAÇÃO NO CONTEXTO DA DEPRESSÃO DO FIM DA IDADE MÉDIA (III).
}

(Continuação) .

VICTOR DEODATO DA SILVA

do Departamento de História da Faculdade de Filosofia, Letras e Ciências Humanas da Universidade de São Paulo.

\section{CAPITULO 4.}

\section{A LEGISLAÇÃO INGLESA.}

Quando da eclosão da Peste Negra na Inglaterra, a conjuntura - apesar de exteriormente brilhante, graças a espetaculares sucessos militares contra a França e a Escócia - apresentava dificuldades decorrentes tanto das tensões políticas internas quanto das guerras externas, com a agravante de sérias perturbações financeiras e consideráveis problemas agrícolas. Convem, todavia, não exagerar a importância de tais dificuldades, destituidas de caráter agudo e dando mesmo a impressão de um desenvolvimento global favorável.

Do ponto de vista político, por exemplo, a permanente tensão entre o rei e os grandes do reino parecia estar sigularmente atenuada, somente se manifestando em incidentes esporádicos. Desde a imposição da Magna Carta a João-Sem-Terra em 1215, a política inglesa flutuava, conhecendo fases transitórias de trégua entre o rei e a nobreza, que atuava sobretudo através do Parlamento, períodos em que o monarca, com habilidade ou graças a golpes mais ou menos disfarçados, conseguia controlar os mecanismos administrativos e etapas em que os grandes impunham o seu controle à administração, obrigando o soberano a aceitar auxiliares, inclusive para a administração de seus 
negócios privados, indicados pelo Parlamento (1). Não nos cabe aquí entrar em pormenores, mas no que diz respeito ao reinado de Eduardo III todas essas situações se verificaram alternadamente, tendo ocorrido em 1341 uma crise entre o rei e o Parlamento e a supremacia parlamentar nas questões administrativas foi o preço que o monarca pagou em troca da obtenção de recursos financeiros para custear suas campanhas na Escócia e na França - mediante um incremento da fiscalidade - renunciando quase por completo às suas prerrogativas de manter um corpo administrativo doméstico e por ele inteiramente controlado e com a possibilidade de ser usado para a neutralização parcial das iniciativas dos ministros ocupantes de cargos oficiais que fossem do desagrado real (2). Por este artifício os reis ingleses conseguiram com frequência impor com uma relativa firmeza a sua orientação administrativa e tal procedimento tinha sido adotado com sucesso por Eduardo III até 1341, quando o aumento de despesas com as guerras em que a Coroa inglesa se envolvera obrigaram-no a concessões de ordem política aos grandes do reino.

Assim, do ponto de vista político, a guerra não era exatamente favoravel an fortalecimento do poder real, mas uma atitude de fraqueza em relação aos adversários da Inglaterra podia apresentar resultados ainda mais negativos. Um tal comportamento provocava quase inevitavelmente uma séria deterioração do prestígio real junto à nobreza, por vezes com consequências fatais, como se verificaria mais tarde com Ricardo II, caracterizando-se plenamente um "trágico dilema" (3): ou fazer a paz e grangear a impopularidade junto aos barões, inconformados com o que consideravam um vexame e tambem com a perda de rendas provenientes de saques e resgates de adversários aprisionados, alem de canalizar para a política externa toda a turbulência da nobreza; ou adotar uma política belicista e se ver, mais cedo ou mais tarde, na contingência de ceder parte do poder político para obter fundos para prosseguir nas campanhas, alem de se sujeitar ao risco de derrotas igualmente solapadoras da autoridade.

Mas, nos importam menos as repercussões políticas da guerra do que seus reflexos econômicos e sociais. Aquí, ha uma consideravel controvérsia (4), estando fora de nossas possibilidades um apro-

(1). - MYERS, England in the Late Middle Ages, pp. 1 sqq. [97].

(2) - Sôbre a crise de 1341, v. McKISACK, The 14th Century, pp. 174 sqq. [32].

(3) . - "The Tragic Dilema" é o título do primeiro capítulo de MYERS, op. cit. [97], onde o problema está exposto de forma sintética e sugestiva.

(4) . - Com a assinatura P. C. (PH. CONTAMINE?), Le coût de la Guerre de Cent Ans en Angleterre, 1965, pp. 788-791 [66] a revista Annales publica o resumo de uma controvérsia desenvolvida nas páginas de "Past and 
fundamento da questão. E inegavel que a guerra — vitoriosa na maior parte do tempo - trouxe benefícios importantes para certos setores da população. A nobreza, com pilhagens e resgates, deve ter tido, no balanço geral, lucro com as campanhas, sobretudo na França, já que a pobreza da Escócia torna improvavel que os resultados materiais tenham sido particularmente animadores, mas cumpre não esquecer que os custos da participação nas campanhas e o eventual aprisionamento de ingleses a serem resgatados por sua vez, tenham contribuido para limita-lo. Admite-se ainda que os armadores que transportavam tropas, mantimentos e equipamentos, bem como os comerciantes fornecedores dessas forças tenham tido os seus negócios ativados e obtido grandes benefícios. Finalmente, ainda no ativo de tal balanço, convem lembrar que, de uma certa maneira. foram os credores estrangeiros da Coroa Britânica, sobretudo os banqueiros florentinos, através da sua falência, devida à insolvência real, que tiveram que arcar com parte importante das despesas (5). Não obstante todos esses aspectos favoráveis e o fato de as campanhas se desenvolverem exclusivamente no exterior, o que deixou incólumes os campos e as cidades ingleses, é duvidoso que a guerra tenha sido econômicamente benéfica para a Inglaterra, considerados sobretudo o aumento da pressão fiscal, congestionando toda a economia e os reflexos negativos no comércio com o Exterior, sobretudo perturbando seriamente as transações com a lã, o principal produto de exportação do reino, verificando-se inclusive uma intervenção real com fins especulativos no setor (6). Assim, no cômputo geral, as guerras devem ter contribuido para tornar desfavoravel a conjuntura econômica inglesa por ocasião da eclosão da Peste Negra - apesar de tal ter se verificado apenas 3 anos depois dos espetaculares sucessos de Crecy e Neville's Cross - e, ao examinarmos os efeitos econômicos e sociais da epidemia, não deveremos nunca perder de vista que eles podem ter sido agravados por uma sido agravados por uma situação de "economia de guerra".

Present", que não pudemos consultar, entre K. B. McFarlane e M. M. Postan, em torno do custo para a Inglaterra, da Guerra dos Cem Anos, com o primeiro julgando-a lucrativa do ponto de vista de economia global e o seu oponente procurando provar que ela foi nociva. Sem ter lido os trabalhos em pauta, uma opinião fundada torna-se muito dificil, mas a partir do resumo confessamo-nos mais impressionado com a argumentação de Postan, ficando a impressão de que, mesmo para a Inglaterra vitoriosa, a Guerra dos Cem Anos foi nociva economicamente (os números de Past and Present em questão são: T. 22, jul. 1962, pp. 3-13, art. de McFARLANE; e T. 27, abr. 1964, pp. 34-53, art. de POSTAN).

(5) . - PERROY, À l'origine d'une économie contractée..., AESC, 1949, pp. 172 sqq. [99]; AMES, The Sterling Crisis of 1337-1339 JEH, 1965, pp. 504 sqq. [58].

174 [99].

(6). - McKISACK, op. cit., p. 24 [32]; PERROY, art. cit., p. 
Mas, o setor em que mais tangíveis se mostram as perturbações é o agrícola. Desde a crise alimentar de 1315-1317, que atingiu duramente a Inglaterra, a agricultura britânica passou por fases alternadas de sucessos e dificuldades, em geral ligadas às flutuações climáticas. Exatamente no momento da eclosão da epidemia verificou-se um forte umidecimento climático, com a região conhecendo a incidência de chuvas torrenciais o contínuas, acompanhadas das consequências habituais (7) e se não se verificaram manifestações de penúria, esse é um fato que talvez se possa atribuir à Peste Negra, que as obscureceu .

A propósito do momento exato do ingresso da praga na Inglaterra existia alguma divergência até recentemente, visto que Gasquet indicava como primeira menção da eclosão da doença a data de 7 de julho de 1348 (8), enquanto Kowalewsky, citando o cronista Robert de Aversbury, falava de sua manifestação por ocasião da festa de São Pedro, no mesmo ano (9). Descoberta mais recentemente, uma crônica de Lynn permite estabelecer que na festa de São João já se manifestavam casos de contágio (10). A designação de Melcombe Regis (atualmente Weymouth) como local de ingresso, na época em permanente contato com o continente e um dos principais portos do período, não tem merecido contestações (11). A ligação se fazia por intermédio das ilhas Jersey e Guernsey, situadas não muito longe da Normandia, onde a epidemia grassou fortemente no verão de 1348 .

De Melcombe Regis, a moléstia difundiu-se pelas imediações, atingindo rapidamente Exeter, Wells e Salisbury, seguindo aparentemente, em linhas gerais, o curso dos rios. Ao atingir Wells, tomou ela o curso do Tâmisa, chegando a Londres em outubro e de lá difundindo-se para o leste, norte e oeste, simultaneamente, o que ocorreu já em princípios de 1349 (12). Acompanhar em pormenores o seu itinerário é uma tarefa desnecessária para o nosso trabalho, mas cumpre acentuar que a parte central da Inglaterra começou a sentir seus efeitos no fim do inverno, atingindo a epidemia o seu auge no verão

(7). - GASQUET, The Black Death of 1348 and 1349, p. 85 [122]); KOWALEWSKY, Die öknomische Entwicklung Europas..., T. 5, p. 229 [147].

(8). - Op. cit., p. 84 [122]; ZIEGLER, The Black Death, p. 120 [143].

(9). - Op. cit., T. 5, p. 239 [147]; ZIEGLER, op. cit., loc. cit.

(10) - CARPENTIER, Autour de la Peste Noire... AESC, p. 1063 [67]; ZIEGLER, p. 119 [143].

(11). - GASQUET, p. 83 [122]; ZIEGLER, p. 120 [143].

(12). - GASQUET, p. 89 sqq. [122]; ZIEGLER, pp. 122 sqq. [143]. 
de 1349 (13), como por exemplo no East-Anglia. O Condado de Derby foi atingido em maio de 1349 e as regiōes setentrionais ainda mais tarde, sendo provavel que ainda em 1350 houvesse áreas em que a epidemia ainda estivesse grassando (14).

A mortalidade foi, sem dúvida, bastante elevada, mas é dificil shegar a uma avaliação exata. A população da Inglaterra no período imediatamente anterior à epidemia foi avaliada por Russell em 3 milhões e 700 mil habitantes (15), cifra que pode ser considerada plausivel e, que, em todo caso, representa uma média de cálculos anteriormente aventados (16) e esse mesmo autor avalia em $20 \%$ a média do desgaste demográfico produzido pela moléstia no reino (17). Todavia, essa seria uma média geral, levando em conta regiões fortemente atingidas - em algumas está comprovada uma mortalidade da ordem de $50 \%$ (18) - enquanto em outras a ausência de referências autoriza até certo ponto a hipótese de terem sido pouco tocadas ou mesmo totalmente preservadas, mas a incerteza que cerca tais indícios faz com que as avaliações mais tradicionais, partidárias de uma mortalidde de um terço, ou mesmo mais, ainda possam ser consideradas bastante verossimeis.

Quando da eclosão da epidemia já parecia estar assentada uma reunião do Parlamento para janeiro de 1349 , a qual, porém, teve que ser suspensa (19), o que não impedia que começassem a multiplicar-se as queixas quanto ao comportamento da mão-de-obra, forçando a intervenção real - com o monarca assistido por seu Conselho - em 18 de junho desse mesmo ano, quando a Peste Negra ainda assolava

(13). - GASQUET, pp. 149 sqq. [122]. Todavia, Aug. JESSOPP, The Black Death in East-Anglia, The Coming of the Friars... [126a], ainda merece atenção no que diz respeito ao East-Anglia, por mais estranhas que sejam suas considerações sobre a origem da epidemia (que ele acreditava oriunda da Escandinávia!). Sobre a difusão da peste no East-Anglia, pp. 208 sqq.

(14). - GASQUET, pp. 141 sqq. [122].

(15). - Não tendo tido acesso à obra de RUSSEL, British Medieval Population. (Albuquerque, 1948), indicamos essa cifra do resumo de $\mathrm{Ph}$. WOLFF et aii, Anthropologie et Démographie... Rapports du IXe. Congrès..., pp. 64 sqq. [55].

(16). - THOROLD ROGERS, Histoire du travail..., p. 104 sqq. [155] e Economic Interpretation of History; pp. 157 sqq. [156], defendia a tese de que a população da Inglaterra não poderia ultrapassar os 2.500 .000 habitantes, enquanto outros, como, KOWALEWSKY, op. cit., p. 406 [147], julgavam que ela pudesse montar ao dobro dessa cifra.

(17). - ABEL, Agrarkrisen und Agrarkonjunktur..., p. 47 [56].

(18). - POSTAN e TITOW, Heriots and Prices in Manchester Manors $E H R$, p. 408 [107], comprovaram uma mortalidade dessa ordem para os manors do arcebispado de Winchester.

(19). - JESSOPP, op. cit., p. 181 [126a]; GASQUET, p. 107 [122];

PUTNAM, The Enforcement of the Statutes of Labourers..., p. 2 [152]. 
importantes regiões do reino. Como já frizamos, no capítulo anterior o documento é classificado, nas fontes como Statutum de Operariis e justificaria considerá-lo já como o Statute of Labourers, o que, contudo, traria o inconveniente de confundi-lo com o diploma legal de 1351, ao qual é geralmente reservada essa classificação. Como este último é mais detalhado em suas disposições e foi promulgado em meio a uma maior solenidade, com a presença do Parlamento, pareceu-nos mais lógico - e sobretudo mais comodo - continuar a reservar-lhe o título de Statute of Labourers, reservando ao ato público de 1349 a classificação de Ordinance of Labourers, ou, mais simplesmente, estatuto e ordenação, respectivamente.

A importância da ordenação de 1349 é das mais consideráveis, representando uma medida sem precedentes na Inglaterra. Isso não significa que nesse reino o Estado nunca tenha interferido na vida econômica, visto que as assize of bread and ale já eram praticadas desde o século XII (20) que, contudo, nada mais representavam do que um controle da distribuição de cereais, inteiramente executados pelas autoridades locais e com o governo real limitando-se a estabelecer normas gerais, enquanto no novo documento interferia em amplos setores da vida econômica e encarregava-se em parte de sua aplicação. Mas, parece-nos que a significação maior do documento não reside no fato de ele constituir uma primeira intervenção real na vida econômica, o que pode ser contestado em vista dos assize of bread, mas no fato de ele representar uma interferência num setor em que as relações estavam secularmente regidas pelos costumes. A modificação dos costumes ainda não passados por escrito, mediante estatuto decretado pelo rei iniciou-se sob o reinado de Eduardo I (1272-1307) mas, alem de restringir-se à regulamentação da administração, sobretudo real, eram objeto de ceticismo quanto à sua validade (21) . O fortalecimento do Estado era tal que o rei decidiu-se em 1349 e 1351, e cada vez mais frequentemente a partir de então, a intervir num domínio até então regido exclusivamente pelo costume, sem que - e aqui carecem de relevância as resistências que a aplicação de tais diplomas legais possa ter suscitado - o direito de faze-lo fosse contestado formalmente. Assim, pode-se dizer que uma nova fase - caracterizada por uma frequente intervenção do Estado na vida econômica - da evolução histórica inglesa se iniciava.

(20) . - ROSS, The Assize of Bread EHR passim [43] e LIPSON, The Economic History of England, Vol. 1, pp. 117 sqq. [148].

(21) . - JOLLIFFE, The Constitutional History of Medieval England..., pp. 334 sqq. e 377 sqq. [28]. 
Passando ao exame do conteudo da Ordinance, na exposição de motivos é evocada a grande mortalidade entre a população, especialmente entre operários e domésticos (maxime operariorum et servientum) e que ninguem, entre os sobreviventes, apercebendo-se (videntes) da necessidade dos senhores e a carência de domésticos, deseja trabalhar, a não ser por salários excessivos, preferindo mendigar a ganhar com seu labor a subsistência. Considerando os danos que poderiam resultar da carência - sobretudo de agricultores e artezãos assalariados - o monarca decidiu deliberar a respeito com prelados e nobres, alem de outros entendidos (peritis aliis) e determinar providências (duximus ordinandum), baseado em opiniões unânimes (de quorum unanimi consilio) (22).

O primeiro ponto a ser assinalado nesse exórdio é a responsabilização da peste pelas anomalias verificadas no mercado de trabalho e, sobretudo, o fato de se afirmar que ela incidiu sobretudo sobre as classes laboriosas da população - questão a que já aludimos acima - o que constitui um testemunho tanto mais valioso por partir de uma fonte oficial.

A indicação de que houve unanimidade de ponto de vista por parte do Conselho Real quanto às medidas adotadas revela que os prelados e grandes do reino aceitaram as considerações dos Commons, aos quais se atribui a maior pressão no sentido de serem tomadas as providências em exame (23), setor da' população constituido sobretudo por pequenos e médios proprietários ou knights, estes últimos incorporados à pequena nobreza, alem dos burgueses. Com efeito, os pequenos proprietários podem ser tidos como os mais prejudicados já que a alta nos salários era acompanhada por uma tendência à baixa nos preços dos produtos agrcolas. A menção de outras pessoas entendidas (peritis aliis), sugere que representantes dos Commons tenham talvez participado das reuniões do Conselho, ao lado dos prelados e grandes do reino. Acentue-se, enfim, que o problema da mão-de-obra aparece claramente como o ponto central da questão e que os trabalhadores sobreviventes demonstraram ter plena consciência da valorização do

(22). - "Quia magna pars populi, et maxime operariorum et servientum, jam in ista pestilentia est defuncta, nonnulli, videntes necessitatem dominorum et paucitatem servientum, servire nolunt, nisi salaria recipiant excessiva, et alii, mendicare malentes, in otio, quam per laborem quaerere victum suum. Nos, pensantes gravia que ex carentia, presertim cultorum et operariorum, hujusmodi prov́enire posent incommoda, super hoc cum prelatis et nobilibus, et peritis aliis nobis assistentibus, deliberationem habuimus et tractatum, de quaorum unanimi consilio duximus ordinandum". RYMER, Foedera, Conventones..., T. 1, p. 198 [5]; THE STATUTES OF THE REALM ..., T. 1, p. 307 [6]; PUTNAM, op. cit., pp. 8-9 (apêndice). [152] [153].

(23). - M. KOWALEWSKY, pp. 426 sqq. [147]. 
trabalho, preferindo a mendicância a trabalhar por salários que não fossem do seu agrado. Todavia, veremos mais adiante que a questão não se apresenta tão simples assim e que, se os preços dos produtos agrícolas sofriam tendências baixistas, isso não podia ser generalizado indiscriminadamente a todo tipo de mercadorias, havendo uma certa tendência à carestia, que servia até certo ponto de respaldo às pretensões dos trabalhadores.

A primeira determinação do documento consiste na obrigatoriedade do trabalho para todos os homens e mulheres válidos do reino cuja idade fosse inferior a 60 anos, em atividades compatíveis com a condição de cada um e pelas mesmas remunerações em curso no $20^{\mathbf{0}}$ ano do reinado de Eduardo III na Inglaterra ou 5 a 6 anos antes da promulgação da presente ordenação (24). A instituição da obrigatoriedade do trabalho, mesmo que estranha às tradições legais inglesas - ao contrário de outros países, como por exemplo Portugal, onde ela já tinha sido estabelecida bem antes da epidemia - é bastante lógica, em face de uma conjuntura aguda de insuficiência de mão-de-obra, mas o estabelecimento de condições de remuneração se apresenta muito mais merecedor de atenção. De fato, tendo começado a reinar em 1327, o $20^{\circ}$ ano do reino corresponde a 1346 e tendo a Ordinance sido promulgada em 1349, os 5 ou 6 anos anteriores nos fazem remontar a um período ainda mais recuado, 1344-1345. Assim, vemo-nos a braços com dois enigmas, um de solução aparentemente facil e outro praticamente indecifravel: a ausência de coincidência entre os dois sitemas de estabelecimento de pontos de referência parece-nos dificil de explicar (25), enquanto o recuo para ao menos 2

(24) . - "Quod quilibet homo et femina regni nostri Angliae, cujuscumque conditionis fuerit, libere vel servilis, potens in corpore et infra etatem sexaginta annorum.... considerato statu suo, fuerit requisitus, servire tencatur illi, qui ipsum sic duxerit requirendum, et percipiat dumtaxat vadia, liberationes, mercedes, seu salaria, que in locis ubi servire debeat, consueta sunt prestari anno regni nostri Anglie vicesimo, vel, annis communibus, quinque vel sex proximo precedentibus". Th. RYMER, loc. cit. [5]; STATUTES, loc. cit. [6]; B. H. PUTNAM, loc. cit. [152].

(25). - PERROY, art . cit., p. 176 [99], menciona uma desvalorização da moeda em 1344. Como veremos imediatamente em seguida, tal medida se insere no contexto de um comportamento financeiro próprio de uma fase de guerra, mas o que o importa é que o documento oferece a possibilidade para escolher entre 3 anos $(1344,1345$ e 1346) aquele que deve servir como paradigma para a fixação das remunerações e aqui perguntamos-nos: seria o caso de supor que as medidas reais para levar avante o esfôrço de guerra - incluindo a deterioração do teor metálico das moedas em 1344 - teria refletido sobre a evolução de salários e preços em anos diferentes conforme a região? O único elemento que permite o levantamento de uma hipótese desse gênero é a manifesta tendência do documento de oferecer, não simplesmente u'a mão-de-obra a preço razoavel, mas sim braços os mais baratos possivel, caso em que o le- 
anos antes do início dos desgastes da epidemia - e não simplesmente ao ano anterior - permite supor que já em 1347 fazia-se sentir uma tendência à alta nos salários, motivada talvez pela guerra com a França, consumidora respeitavel de mão-de-obra (26) e tambem de fundos financeiros, obrigando Eduardo III a uma desvalorização da libra, mediante enfraquecimento de seu teor em metal precioso em 1344 (27) . O ano de 1346, o da batalha de Crecy, marcou um dos pontos culminantes do esforço de guerra ingles, não sendo, porem, impossivel que os seus efeitos econômicos somente se tenham feito sentir a partir do ano seguinte. Por outro lado, a inter-ligação entre a guerra e a peste não se restringe a tal problema, motivo pelo qual voltaremos com uma certa frequência à questão.

Todavia, a aplicação do princípio da obrigatoriedade do trabalho não era feita a esmo e ele não incidia sobre os que viviam do comércio, exerciam o artezanato, tivessem bens próprios para sustenta-los ou fossem proprietários de terra que devessem cultivar (28), o que limita consideravelmente o seu raio de ação. Antes, porém, de passarmos a outro item, convem frizar que, implicitamente ficavam excluidos da submissão ao trabalho compulsório os que tivessem enriquecido graças à percepção de heranças deixadas por vítimas da epidemia, os quais, na Inglaterra como em todas as regiões devastadas pela epidemia, deviam ser bastante numerosos (29).

A cláusula seguinte reveste-se de grande significação, inclusive denotando uma certa contradição. Por ela, os antigos senhores (domini) tem garantida a preferência na requisição dos serviços dos trabalhadores em disponibilidade, o que indicaria o desejo de reforçar os laços de dependência. Todavia, tal interpretação se torna incerta

gislador deixaria às autoridades de cada lugar a escolha - dentre 3 anos possivelmente de baixa nos salários - de 1 ano em que as remunerações tinham sido particularmente módicas. Todavia, insistimos, trata-se de mera especulação na falta de explicação mais lógica, motivo pelo qual somente ousamos aventa-la em nota.

(26). - Segundo P. C. art. cit., p. 789 [66], Postan calcula as forças inglesas presentes em Crecy - entre combatentes e não-combatentes - em cerca de 60 a 80.000 homens, correspondente a entre 2 e 2,5\% da população inglsa, a $10 \%$ ou mais dos adultos masculinos entre 18 e 45 anos e o equivalente a 750.000 da Inglaterra atual.

(27). - Ed. PERROY, art cit., p. 176 [99].

(28). - "... non vivens de mercatura, nec excercens artificiam, nec habens de suo proprio unde vivere, vel terram propriam, circa culturam cujus se poterit occupare..." RYMER, loc. cit. [5]; STATUTES, loc. cit. [6]; B. H. PUTNAM, loc. cit. [152].

(29). - LAW, The English "Nouveaux-riches" in the 14th Century TRSH, pp. 71 sqq. [127]; THOMPSON, Economic and Social History of Europe... p. 384 [159]. 
em seguida, ao ser estipulado que nenhum senhor deve reter mais servidores alem dos que sejam estritamente necessários (30). Inicialmente, ressalte-se que o contexto não permite dúvidas quanto ao fato de que se trata especificamente de dependentes (vilões e bondmen) e temos ai um sintoma de que os laços entre estes e os respectivos senhores já demonstravam uma pronunciada frouxidão, ainda que não se deva generalizar a respeito, pois no sul ainda havia regiões onde eles se mostravam bastante vigorosos (31). Admite-se em geral que a Peste Negra, se não interrompeu, ao menos perturbou um processo já bastante adiantado de substituição da prestação de serviços por pagamentos em dinheiro, na medida em que valorizou a servidão, já que esta representava mão-de-obra garantida (32). Quaisquer que tenham sido os embaraços que a epidemia tenha oposto à emancipação dos dependentes - e em alguns casos eles foram consideráveis - a interdição aos senhores de manter a seu serviço um número maior de trabalhadores do que o estritamente necessário - e aquí se incluem os dependentes — indica que a distinção entre vilãos e livres já se encontrava bastante reduzida, devendo-se ressaltar que, quando da aplicação do documento ora em exame, os juizes não a levavam em con-

(30). - "Proviso quod domini preferantur aliis in nativis, seu terran suam nativam tenentibus, sic in servicio retinendis; ita tamen quod bujusmodi domini sic retineant tot, quot sibi fuernt necessarii et non plures". RYMER, loc. cit. [5]; STATUTTS. VII, loc. cit. [6] B. H. PUTNAM, loc. cit. [152].

(31). - Éd. PERROY, art. cit. p. 181 [99].

(32). - TH. ROGERS, Histoire du Travail..., pp. 198 sqq. [155] e Economic Interpretation of History, pp. 23 sqq. [156] defendeu a tese segundo a qual o processo de substituição dos serviços por pagamentos em dinheiro já se encontrava completado por ocasião da epidemia e que os conflitos entre os senhores e trabalhadores resultavam das tentativas dos primeiros em forçar uma reversão à prestação de serviços, mas a procedência de tal hipótese não merece mais aceitação. Para críticas v. PETIT-DUTAILLIS, Introduction Historique in REVILLE, Recherches sur le soulèvement..., pp. xxxiii sqq. [154a] e étude historique in STUBBS, Histoire Constitutionnelle de l'Angleterre, pp. 854 sqq. [157a]; CUNNINGHAM, The Grouth of English Industry..., pp. 329 sqq. [20]; ASHLEY, The Economic Organization of England..., pp. 49 sqq. [144]; LIPSON, op. cit., T. 1, pp. 94 sqq. [148]; OMAN, The Great Revolt in 1381, pp. 5 sqq. [151] entre muitos outros. Tais trabalhos, em geral antigos, mostram porém que durante muito tempo a teoria de $\mathrm{Th}$. Rogers se constituiu num "divisor de águas". Outro ponto da teoria de Th. Rogers discutido é o de que do atrito entre senhores e dependentes é que teria resultado um êxodo maciço dos manors, sendo que no caso das terras da abadia de Westminster, B. HARVEY. The Leasing of the Abbot of Westminster's Demesnes..., EHR, 1969, passim [78] comprovou que, em alguns casos, a epidemia até mesmo retardou o processo, já iniciado em fins do século XIII. Para uma visão de conjunto sintética, atual e desprovida de polêmicas, vide M. McKISACK, pp. 333 sqq. [32]. 
ta (33). Ao mesmo tempo, a providência interditando aos senhores a retenção de um número de trabalhadores superior ao necessário, prestava-se à ocorrência de abusos, com senhores que gozavam de influência junto às autoridades obtendo a subtração em seu proveito de servidores dos seus vizinhos (34).

Para garantir o sucesso na aplicação das medidas determinadas no documento, prevêm-se a seguir numerosas medidas punitivas, a atingir tanto os trabalhadores quanto os empregadores faltosos. Em relação aos indivíduos, homens ou mulheres, aos quais se aplicasse o princípio da obrigatoriedade do trabalho e que, tendo tido seus serviços requisitados, se recusassem a obedecer $\mathrm{e}$ isto fosse atestado na presença da autoridade local (coram vicecomite, Ballivo domino aut Constabulario ville) por 2 homens bons (fideles homines), deveriam ser rigorosamente custodiados na cadeia mais próxima até que se resolvessem a servir dentro das normas prescritas, extendendo-se tal penalidade aos trabalhadores - agrícolas (messor, falcator), artesãos (operarius) ou qualquer tipo de servidor (serviens), de qualquer estado ou condição que fosse - que abandonassem as tarefas para as quais tivessem sido contratados, antes do prazo estipulado, sem motivo razoável ou sem permissão (35). Trata-se, portanto, de medidas que visavam tanto a obrigar os inativos ao trabalho, quanto a fixar os trabalhadores em s̀eus postos, estando os dois problemas, aliás, profundamente interligados, pois os desocupados eram, na sua maioria, servidores que tinham abandonado seus postos.

Mas, antevia-se já que o maior obstáculo partiria dos próprios senhores, visto que aqueles dentre estes que se vissem privados de mão-de-obra em consequência, direta ou indiretamente, da epidemia, acabariam por tentar obtê-la, mesmo ao preço da burla da presente ordenação. Assim, o documento estabelece, imediatamente em seguida, que ficam sujeitos à mesma pena de prisão aqueles que recebam ou retenham a seu serviço trabalhadores que tivessem abandonado suas ocupações (36). Embora fossem frequentes os processos de se-

(33). - "... the effect of the legislation on free and unfree was identi$\mathrm{cal}$ and that for this reason no distintcion between the two categories had to be made by the justices". B. H. PUTNAM, p. 78 [152].

(34). - B. H. PUTNAM, p. 93 [152] registra o caso de um abade que apresentou ao rei queixa contra juizes que obrigaram seus servidores a passarem ao serviço de senhor vizinho, determinando o monarca que lhe fossem obtidos os trabalhadores de que o queixoso necessitava.

(35) .- - RYMER, loc. cit. [5]; STATUTES, loc. cit. [6]; PUTNAM, p. 9 (apêndice) [152].

(36). - "Et nullus, sub eadem pena, talem in servitio suo recipere vel 
nhores contra senhores por usurpação da mão-de-obra (37), pode-se duvidar do resultado da presente medida, pois a analogia com a situação dos servidores recalcitrantes é apenas aparente, sendo duvidoso que os empregadores, uma vez surpreendidos, insistissem em reter os referidos trabalhadores. Em relação a estes, sobretudo os que se dedicavam à vadiagem, o que já indicava a disposição de somente trabalhar por remuneração de seu agrado, a detenção podia, eventualmente, ter algum efeito persuasivo.

Mais efetivas no combate às perturbações ocasionadas pelo surgimento da concorrência no mercado de trabalho se nos afiguram as determinações subsequentes, a recair tanto sobre os empregadores que pagassem remunerações superiores às estabelecidas quanto sobre os empregados que as aceitassem. Num e noutro caso ficavam os infratores sujeitos a úma punição pecuniária (38) correspondente ao dobro das importâncias pagas ou recebidas, a reverter à parte que se sentisse prejudicada e fizesse a denúncia, sendo que se nenhuma das partes se manifestasse, qualquer pessoa do povo poderia faze-lo junto ao tribunal senhorial local, tornando-se beneficiária da referida punição (39). Estas determinações revelam com meridiana clareza que não se ignorava que nos casos em que a mão-de-obra fosse particularmente escassa, por terem sido mais acentuadas as devastações da peste, acordos de salários superiores aos permitidos podiam ser combinados, o que reduziria o alcance da legislação, já que muitos empregadores preferiam obter servidores a preços mais elevados do que de hábito, a arriscarem-se a deles ficarem privados.

Mais ainda, os elaboradores da Ordinance deviam prever que os que menos se predisporiam a curvar-se às suas normas seriam os grandes do reino, já que se estabelece a seguir que quaisquer senhores, de

retinere presumot". Referências idênticas às da nota anterior.

(37). - B. H. PUTNAM, pp. 179 sqq. e p. 223 [152].

(38). - Aquí cumpre ressaltar ser impróprio o uso do termo "multa", devendo-se distinguir entre elas e os excesses ou pagamentos a mais. No caso dos excesses o montante da punição era determinado pelas importâncias envolvidas nas transações, o que não ocorria com a multa. B. H. PUTNAM, p. 84 [152].

(39). - "Nullus eciam vadia, liberationes, mercedes, seu salaria majora solito, sicut predictum est, alicui solvat vel solvere promittat nec aliquis ea alio modo exigat vel recipiat, sub pena dupli illius quod sic solutum, promissum fuerit, aut exactum vel receptum, illi qui ex hoc se senserit gravatum; et nullo tali volente prosequi, tunc cuicumque de populo, qui hoc prosecutus fuerit, apllicant; et fiat hu usmodi prosecutio in curia domini loci, quo talis casus acciderit". RYMER, T. 1, p. 198 [5]; STATUTES..., T. 1, p. 307 [6]; PUTNAM, p. 10 (apêndice) [152]. 
cidades (villae) ou manors que desacatassem as presentes normas em exame, em pessoa ou por intermédio de seus intendentes (ministri), deveriam ser conduzidos às barras dos tribunais locais e condenados ao pagamento do triplo do que tivessem pago ou prometido pagar aos trabalhadores contratados, que excedesse os máximos permitidos (40). E interessante observar que a penalidade prevista para os nobres é sensivelmente mais pesada do que a preconizada para os empregadores comuns - o triplo e não o duplo dos salários pagos a mais - mas, em compensação, estavam eles sujeitos a foro especial - os tribunais locais, mas reais: comitatibus (nos condados), wapentachiis (Wapentakes), trithingis (tithings) e outras cortes similares - tribunais compostos por nobres, visto que admitia-se que os nobres somente poderiam ser julgados pelos seus pares, o que permite colocar em dúvida a sua severidade.

Finalmente, ainda no capítulo das generalidades sobre as remunerações dos servidores - e é util acentuar que se trata de medidas concernentes sobretudo à mão-de-obra rural - ficam anuladas as disposições de contratos estabelecidos anteriormente à promulgação da ordenação em que estivessem previstos salários que excedessem os limites máximos nela estipulados, pelos serviços prestados, ficando os contraventores sujeitos às penalidades enumeradas nos itens anteriores (41).

Até aqui tratou-se apenas dos aspectos mais gerais da regulamentação do trabalho e sua remuneração e - como já acentuamos essas disposições se aplicavam sobretudo à mão-de-obra rural. A partir deste ponto entramos em aspectos mais específicos e relevando predominantemente das atividades mais características dos centros urbanos: o artesanato e o comércio. Para os artesãos em geral - são citados seleiros (sellarii), peleiros (pelletarii), curtidores (allutarii), sapateiros (sutores), alfaiates (cissores), ferreiros (fabri), carpinteiros (carpentarii), pedreiros (cementarii), telheiros ou cobridores de casas (tegularii), construtores de navios ou mestres de estaleiro (batellarii) e fabricantes de carroças (carectarii), mas a medida se extende a todos os demais artífices e operários (et quicumque alii artifices et operarii) - estabelece-se que deverão cobrar pelos seus serviços o mesmo que cobravam no já mencionado $20^{\circ}$ ano do reinado de Eduardo III ou nos $5^{\circ}$ ou $6^{\circ}$ anos comuns anteriores à promulgação do documento,

(40). - "Et si domini vallarum vel maneriorum, contra presentem ordinationem nostram per se vel ministros suos, in aliquo venire presumpserint, tunc in comitatibus, wapentachiis, et trithingis, vel aliis curiis nostris hujusmodi, ad penam tripli, per eos, vel ministros suos, sic soluti vel promissi, in forma libus solvi consuevit..." Referências idênticas às da nota anterior.

(41). - Referências idênticas às das notas anteriores. 
sob pena de detenção (42). Embora aqui não se trate propriamente de salários na maior parte dos casos e sim de tarifas de serviço, deve-se notar que, em última análise, são problemas ligados à carência de mão-de-obra, estando com isso plenamente caracterizada a analogia com os casos anteriormente regulamentados, o que explica a similitude das soluções.

Os artesões, por outro lado, são obrigados a ceder seus serviços nos locais de trabalho, medida destinada sem dúvida a facilitar o controle na observância das prescrições em exame, o que era tanto mais facil se considerarmos que os praticantes de um mesmo ramo de artesanato em geral se concentravam numa mesma zona da cidade (43). Deve-se também lembrar que as limitações nos preços representavam um consideravel prejuizo para os artesãos, sendo que aqui seria muito pouco cabivel uma distinção entre empresários e assalariados, pois, de um lado, os donos de oficina eram os próprios mestres e, de outro, o emprego da mão-de-obra assalariada era bastante limitado, como demonstrou Geremek (44). A não ser em setores muito estritos como o dos tecidos, e ainda assim em regióes muita especializadas em sua fabricação, como a Toscana e os Países-Baixos - a dicotomia hoje de regra entre o empresário, ou seja aquele que tem o controle financeiro do empreendimento, e o operário, no caso aquele que executa os serviços, ainda não existia. Os compagnons e aprendizes tinham com os mestres laços ainda próximos dos de dependência feudal, aloiando-se e alimentando-se na casa deste e recebendo apenas algum dinheiro para pequenas despesas. Mas até que ponto a Peste Negra teria deixado incólume essa forma de organização do trabalho? Parece-nos provavel que a moléstia, tendo feito numerosas vítimas entre os mestres, abriu caminho à promoção para os compagnons e mesmo para os aprendizes, permanecendo, porém, o problema do preenchimento dos claros verificados nas fileiras destes, seja por morte, também por ação da epidemia, seja por promoção ao grau e posição de mestres. Assim, a situação no setor artesanal deve ter se complicado consideravelmente e seria pelo menos lógico, já que não sabemos de pesquisas

(42). - "Item quod... (segue enumeração de ofícios) non capiant pro labore et artificio suo, ultra id quod, dicto anno vicesimo, et aliis communibus annis precedentibus... et si quis plus receperit, gaole proxime, modo quo premittitur, committatur". RYMER, loc. cit. [5] STATUTES..., T. 1, p. 308 [6]; PUTNAM, p. 10 (apêndice) [152].

(43). - "... ut premittitur, in locis quibus eos operari contigerit, talibus solvi consuevit..." Referências idênticas às da nota anterior.

(44). - Les salaires et le salariat dans les villes au cours du Moyen Âge, 3 me. Conférence Intern. d'Hist. Econ., 1965, passim [23]; v. tb. Le salariat dans l'artisanat parisien..., p. 145 [24]. 
nesse sentido, que tivesse havido um incremento na utilização de assalariados.

Passando aos fornecedores de produtos alimentares a legislação em causa, ainda que mantendo a mesma severidade no tom da redação, é menos taxativa em relação ao estabelecimento dos preços a serem cobrados, fato que originou alguma controvérsia. Os vendedores de alimentos - açougueiros (carnefices), peixeiros (piscenarii), bodegueiros (hostellarii), cervejeiros (braciatores), padeiros (pistores), vendedores de aves (pulletarii) e todos os demais vendedores de alimentos de qualquer tipo (omnes alii venditores victualium quorumque) - são instados a vender os seus produtos por preços razoáveis, similares aos das localidades vizinhas, de forma a ter lucros moderados, proporcionais à distância dos locais de onde deviam ser transportados em relação àqueles onde deveriam ser vendidos; sob pena de pagar o dobro das importâncias recebidas à parte lesada ou, caso não houvesse queixa da parte desta, a qualquer pessoa que denunciasse a transação, penalidade cuja aplicação já tínhamos visto preconizada em relação aos salários (45).

A favor do legislador poderia ser alegado que, mais do que os salários, os preços dependem de múltiplos fatores, e embora se mencionem apenas os custos de transporte está implícita a admissão de flutuações de preços de uma região para outra conforme o artigo considerado, as quais seriam explicáveis tanto pelo maior ou menor sucesso nas colheitas quanto pela produção ou não no local da mercadoria considerada. Uma vez levadas em consideração pelo legislador tais circunstâncias, teríamos ai uma explicação para o contraste entre a relativa flexibilidade das medidas relativas aos preços - mas somente dos produtos alimentícios, ao menos nesta primeira ordenação - e a rigidez das concernentes aos salários.

Todavia, o problema não foi encarado exatamente dessa forma por alguns historiadores que dele cuidaram. Assim, alegou-se e aqui teríamos uma posição favoravel ao comportamento real na questão que o legislador julgou que uma vez que foi o setor dos salários o que

(45) . - "Item, quod... - segue enumeração dos fornecedores teneantur hujusmodi victualia vendere pro pretio rationabili, habita consideratione ad pretium quo hujusmodi victualia in locis propinquis venduntur; ita quod habent hujusmodi venditores moderatum lucrum, non excessivum, prout distancia locorum a quibus victualia hujusmodi cariantur, duxerit rationabiliter requirendum. Et si quis victualia hujusmodi alio modo venderit, et inde in forma predicta convictus fuerit, solvat duplum illius, quod receperit, dampnificato vel, in defectum illius, alteri qui prosequi voluerit in hac parte". RYMER, T. 1, p. 199 [5]; STATUTES..., loc. cit [6]; PUTNAM, loc. cit. [152]. 
mais se ressentiu dos efeitos da epidemia, acreditava-se que uma vez corrigidas as anomalias ali verificadas, os preços voltariam rapidamente à normalidade (46). Outros - é verdade que ressaltando também o fato de que em relação aos salários a Ordinance fixa um máximo, mas não um mínimo - acusam o governo de parcialidade a favor de um setor da população (47). Pode-se admitir que o último ponto de vista é até certo ponto bem fundado, já que - ao contrário do que acontece, por exemplo, com a ordenação francesa - a legislação inglesa parece ressaltar menos o interesse do consumidor. Seria, porem, imprudente levar muito longe o paralelo entre as legislações inglesa $\mathrm{e}$ francesa, já que à última, em primeiro lugar, se aplicava apenas a uma região restrita quanto à sua extensão - a de Paris - e dizia respeito a uma economia afetada não apenas pela peste, mas tambem pelas devastações da guerra e por desordens monetấrias muito acentuadas, enquanto aquela se aplicava a toda uma nação e visava sobretudo combater as sequelas da epidemia, que tinham refletido sobretudo no setor dos salários. Mas, o que nos parece decisivo acima de toda e qualquer outra consideração é que os preços - sobretudo de alimentos, exatamente aqueles em relação aos quais as autoridades demonstravam maior flexibilidade - estiveram longe de apresentar tendência altista tão pronunciada (48) e que, na medida em que existiu, podia ser compreensivelmente atribuida a uma alta salarial e à insuficiência da mão-de-obra disponivel, o que explicaria que a atenção do governo se voltasse sobretudo para estes últimos problemas.

Em relação às organizações de trabalhadores e profissionais a Ordinance é omissa - ao contrário, como veremos, de suas congêneres francesas, aragonesas e castelhanas - pois as corporações se encontravam sob o controle das autoridades, sobretudo municipais (49), e se constituiam mesmo em instrumentos eficientes de regulamentação salarial. Mas ao lado dessas sociedades oficialmente reconhecidas e controladas havia - e elas tenderam a multiplicar-se após a promul-

(46). - CUNNINGHAM, op. cit., pp. 335 sqq. [20].

(47). - "In any case, however, prices did not remain constant, and while the Government certainly did order that prices should be "reasonable", the term was elastic and would be variously interpretod.... The Act, moreover, fixed the maximum, but not a minimum wage. On the whole then, the Statute of Labourers must be regarded as a one-sided piece of legislation, un unfair exercise of political power in the interests of a single class of the community". E. LIPSON, Vol. 1, pp: 116-117 [148].

(48). - W. ABEL, p. 286 [56], atribui um preço médio de menos de $10 \%$ superior para a década de $1351-1360$ em relação à de 1341-1350, verificando-se uma alta acentuada para a década 1361-1370, para os cereais panificáveis.

(49) . - W. CUNNINGHAM, pp. 338 sqq. [20]; E. LIPSON, Vol. 1, pp. 118 sqq. [148]. 
gação da legislação sobre os salários - outras de caráter espontâneo e fundamentadas apenas num sentimento de solidariedade mútua e que contavam entre os seus objetivos a luta por melhores remunerações. Contra estas o documento faz ameaças de repressão ao determinar aos magistrados e oficiais reais encarregados de aplicar a ordenação que ao punir de acordo com seus dispositivos o fizessem sem levar em conta os grupos (sectae) a que os faltosos pertencessem (50). Esse inciso revela que, antes mesmo da promulgação do diploma legal em exame, os conflitos entre os senhores e os trabalhadores já tinham assumido características suficientemente ásperas para que estes já constituissem ligas de defesa mútua (51). As sucessivas reiterações da Ordinance, por seu lado, levaram os trabalhadores - sobretudo, embora, como veremos mais adiante, não exclusivamente rurais - a acentuar a sua resistência, contribuindo tal situação para a eclosão da grande revolta de 1381 .

Pelo item que acabamos de examinar verifica-se que a aplicação dos dispositivos da ordenação ficava entregue às autoridades locais. Todavia, para dar ênfase à importância que o rei atribuia à obșervância do documento, anuncia-se em seguida a designação de juizes especiais, primordialmente com a função de supervisionar o comportamento das autoridades locais na aplicação dos dispositivos da Ordinance. Os bailiffs e mayors que se mostrassem negligentes nessa tarefa deveriam pagar às partes prejudicadas o triplo das importâncias pagas a mais - ou na falta de manifestação destas, a quem quer que fizesse a denúncia - sem prejuizo de penalidades mais graves conforme o julgamento do soberano (52). Tal dispositivo reveste-se de consideravel significação,poi s representava a intervenção real sistemática num setor que, costumeiramente, era essencialmente da alçada da justiça lo-

(50). - "Et habeant potestatem major et ballivi... ad inquirendum de omnibus et de singulis, qui contra hoc in aliquo deliquerint et ad penam predictam, ad opus illorum, ad quorum sectam hujusmo di delinquentes convicti fuerint, levandum" RYMER, loc. cit. [5]; STATUTES..., loc. cit. [6]; PUTNAM, pp. 10-11 (apêndice) [152].

(51). - LIPSON, T. 1, pp. 103 sqq. [148]; TH. ROGERS, Histoire du travail..., pp. 222 sqq. [155]; PETIT-DUTAILLIS in STUBBS, op. cit., p. 860 [157]; McKISACK, pp. 335 sqq. [32].

(52). - "... et in casu quo iidem major et ballivi, executionem premissorum facere neglexerint et de hoc coram justiciariis per nos assignandis, convicti fuerint, tunc iidem, major et ballivi, ad triplum rei sic vendite, hujusmodi dampnificato, vel alteri $\mathrm{n}$ defectum llius prosequenti, solvendum per eosdem justiciarios compellantur, et nichilominus versus nos graviter puniantur". RYMER, loc. cit. [5]; STATUTES..., loc. cit. [6]; PUTNAM, p. 11 (apênd.) [152]. 
cal e representa uma etapa importante para a instituicionalização dos juizes de paz (53).

Já próximas do fim do texto legal surgem novas disposições concernentes à vadiagem, o que revela a consciência da gravidade do problema, mas que desta vez não atingem os mendingos em condições de trabalhar, mas sim os que os estimulavam a permanecer nesse modo de vida, favorecedor - segundo o próprio documento - do florescimento de vícios, incluindo o roubo. Assim, são ameaçados de prisão os que, a pretexto de piedade ou caridade, deseja lá o que for a quem estivesse em condições de trabalhar, a fim de compeli-los a ganhar a vida comi o seu próprio labor (54). Esta disposição poderia dar a impressão de que, sob a ameaça da aproximação do juizo final, por ocasião da incidência da epidemia, as camadas mais favorecidas da população passassem por uma fase de espírito caritativo, a manifestar-se por doações pias e esmolas, mas com relação a estas últimas porque quanto às primeiras, não resta qualquer dúvida - somente existem conjecturas, visto o assunto, tanto quanto seja do nosso conhecimento, não ter sido sistematicamente estudado (55). No presente caso; de qualquer forma, sabe-se que este é um dos dispositivos menos aplicados de toda a legislação em exame (56) e - ainda que isso não prove que esse tipo de esmola era dado muito raramente o aspecto mais importante nos parece residir na constatação implícita, pelo legislador, de um desenvolvimento anormal da marginalidade.

Atualmente, pode-se afirmar que não há dúvidas de que a Peste Negra tenha tido uma sensivel influência no incremento da marginalidade, mas, no caso ingles ao menos, supõe-se que tal tendência já

(53). - Tais juizes eram inicialmente conhecidos como Keepers of the Peace (poderíamos traduzir por "Guardiões da Paz") e a sua conexão com os problemas "trabalhistas" foi um tanto flutuante - ora dêles divorciado, ora com jurisdição a seu respeito repartida com outras modalidades de juizes, ora deles cuidando com exclusividade, bem entendido na esfera real, por que na local os bailiffs e mayors sempre se constituiram nas epltoridades por excelência - ficando estabilizada sua jurisdição a partir de 1361. V. PUTNAM, The Transformation of the Keepers of the Peace... TRHS, 1929, passim, mas sobretudo pp. 43 sqq. [153].

(54). - "Et quia multi validi mendicantes, quamdiu possent ex mendicatis' elemosinis vivere, laborare renuunt, vacando otiis et peccatis, et quandoque latrociniis et aliis flagitis, nullus, sub pena imprisonamenti predicta, talibus qui commode laborare poterunt, sub colore pietatis vel eleemosine, quicquam dare, seu eos in sua desidia confovere presumat, ut sic compellantur provite necessariis laborare". RYMER, loc. cit. [5]; STATUTES, loc. cit. [6]; PUTNAM, loc. cit. [152].

(55) . - V. DEODATO DA SILVA, As migrações numa conjuntura..., p. $170[145]$.

(56). - B. H. PUTNAM, p. 77 [152]. 
vinha se configurando antes de suas devastações (57). O fenômeno foi generalizado em toda a Europa Ocidental e, por si só, constitui um sintoma expressivo de grandes desajustes econômicos e sociais, o que não implica em ser facil a construção de um "modelo" em escala européia para explica-lo. Em todo caso, a raiz do problema parece residir num êxodo rural maciço e na presunção de que nem todos os emigrantes tivessem êxito na sua iniciativa, multiplicando-se os exemplos de desajuste social. Esboçada anteriormente, ganhando contornos nítidos com a Peste Negra de 1348 e acentuando-se com as reincidências uma sensivel contração no mercado consumidor de produtos agrícolas colocou as populações rurais sob uma dupla pressão: a dificuldade de obter remuneração conveniente por seu trabalho no campo e a perspectiva de conseguir uma situação mais favoravel nas cidades, onde a mortalidade atingiu aparentemente índices particularmente elevados, pululando os claros nos vários setores profissionais. No caso da Inglaterra estavam em jogo ainda outros fatores: a guerra, ao fazer com que se verificasse uma redução na exportação da lã (sobretudo para os Países-Baixos, mas também para outras regiões) apresentou a contra-partida de um desenvolvimento da indústria de tecidos, verificando-se mesmo casos em que - como por exemplo York - a população não apenas não diminuiu, mas inclusive aumentou substancialmente (58), fenômeno evidentemente inexplicavel pela exclusiva natalidade local, tendo a imigração de rústicos tido certamente um papel essencial.

Contudo, a falta de habilitação profissional desses emigrantes e a rigidez dos regulamentos corporativos - aliadas ao fato de que a depressão que atingia os campos reduzia, por sua vez e num verdadeiro círculo vicioso, o consumo dos artigos produzidos nos centros urbanos, que tinham na zona rural um mercado significativo - impedia o seu ajustamento profissional, daí resultando uma proliferação das categorias não produtivas da população. Deve-se ainda ter em mente que o retôrno de camponeses emigrantes sempre constituiu uma exceção e, em vista dessa constatação, mesmo que o êxodo rural atingisse proporções tais, que provocasse - o que ocorre, por exemplo, no caso da legislação que estamos examinando - um sério problema de carência de mão-de-obra agrícola, a alternativa para a não-integração

(57). - M. McKISACK, pp. 205 sqq. [32].

(58). - "Some of the principal sources of Yorks" prosperity at a later date were thus of little importance at the opening of the 14th century and it is possible that the population of York was then at its lowest point between 1300 and 1350". BARTLETT, The Expansion and Decline of York in he Later Middle Ages, $E H R, 1959$, p. 21 [59]. A cidade teria atingido em 1377 a posição de a mais povoada do país, depois de Londres, com aumento incessante de sua população (p. 23). 
profissional e social nas cidades era encontrada na mendicância ou outras formas mais agressivas de marginalidade (59).

O problema do abandono dos campos tem sido, por outro lado, objeto de pesquisas intensas - tendo tido em Abel o seu grande pioneiro, ou pelo menos o primeiro que o estudou de um ponto de vista mais global (60) - mas há bastante divergência quanto à importância da Peste Negra no desenvolvimento do processo, constituindo o principal índice de aferição da intensidade da emigração rural as deserções de aldeias, na medida em que tenham resultado no seu desaparecimento completo e em larga escala. $\mathrm{O}$ assunto tem sido exaustivamente estudado na Inglaterra, existindo inclusive um organismo especialmente constituido para esse fim (Deserted Medieval Village Group) e que, aliás, não limita suas atenções aos lost villages medievais, mas também às do período moderno e início do contemporâneo. A tendência de seu fundador e principal animador e tambem a grande autoridade na questão no que concerne à Inglaterra, Beresford, é a de limitar o papel da Peste Negra no surgimento dos lost villages, considerando-a mais como precipitadora do que como causadora do abandono de aldeias, e mesmo assim somente em casos de localização destas em terras de má qualidade e já bastante debilitadas antes da epidemia (61), o que o torna adepto, ao menos parcialmente, da teoria das terras marginais para a explicação dos efeitos econômicos e sociais da moléstia (62). Apenas para que o problema fique bem situado, lem-

(59). - Aspectos genéricos do problema em LE GOFF e ROMANO, Paysages et peuplement rural...ER, 1965, passim [29]; GLENISSON et alii, Les Decouvertes. .., pp. 84 sqq. [74]; HEERS, L'Occident... pp. 93 sqq. [79].

(60). - Die Wüstungen des ausgehenden Mittelalters (1a. ed.: 1943) [57] se constitui na sua obra principal sobre o assunto, mas ele retomou a questão em outras oportunidades como em Agrarkrisen..., pp. 81 sqq. [56] e "Desertions rurales..." in Villages désertés et histoire économique... passim [112d]. Em relação à Alemanha constatou ele que a maior parte dos abandonos de aldeias verificou-se no fim da Idade Média e para tanto a Peste Negra teria contribuido indiretamente, pois - juntamente com outras catástrofes dizimadoras de populações - teria forçado uma redução do consumo de produtos agrícolas a partir da segunda metade do século XIV e acelerado o êxodo rural, quando então teria se verificado a desaparição maciça de aldeias (Die Wüstungen..., parte II, pp. 71 sqq.). Abel tende a englobar nesse processo outras regióes da Europa Ocidental, como a parte setentrional da França e a Inglaterra, mas tal interpretaçāo tem merecido reservas, como se verá em seguida por ocasiano do exame das idéias de Beresford.

(61). - BERESFORD,The Lost Villages of England, pp. 158 sqq. [60] e "Villages désertés: bilan..." in "Villages désertés..." pp. 535 sqq. [112e].

(62) . - No caso do Lincolnshire, onde a ocupação de más terras parece ter sido particularmente frequente a Peste Negra pode ser tida como o golpe de misericórdia para umas 33 entre 113 desaparecidas (cerca de 35\%). BERESFORD, op. cit., pp. 177 sqq. [60] e VAN BATH, The Agrarian History of Western Europa..., pp. 137 sqq. [51]. 
bremos que para Beresford, a época áurea da extinção de aldeias foi do século XV e o início do XVI, em que se multiplicaram as enclosures (encercamentos), o que faz com que o fenômeno possa ser atribuido essencialmente a uma mudança no regime de propriedade (63). Ressalte-se, porem, que se o papel da epidemia foi limitado em relação ao aparecimento dos lost villages, acentuou ela de qualquer forma a mobilidade das populações rurais, fato de que a Ordinance constitui testemunho eloquente.

Em seguida, e aqui voltamos do exame do documento, dirigindo-se diretamente aos sheriffs de toda a Inglaterra, determina o rei a aplicação das normas da Ordinance, no seu todo ou em parte (omnia et singula) em todas as cidades, burgos, centros mercantis, portos de mar e outras localidades das áreas sob sua jurisdição (civitatibus, burgis et villis mercatoriis, portubus maris et aliis locis in balliva tua), respeitando ou não as franquias (tam infra libertates quam extra), de que as ditas comunidades sejam portadoras (64). Esta recomendação permite atribuir ao documento um caráter de típica medida de exceção, visto serem por ele anuladas regalias incorporadas aos direitos locais, agindo, porem, Eduardo III de pleno direito, já que as franquias em questão, concedidas que eram pelo rei, podiam por ele ser suspensas sempre que as circunstâncias assim o determinassem.

Finalizando, o rei conjura os sheriffs a não omitir nenhuma providência que possa contribuir para a salvaguarda dos interesses da Coroa e do reino e, em seguida à assinatura do monarca e dos membros do seu Conselho, recomenda-se que cópias do documento deverão ser enviadas a cada um dos sheriffs (65).

Este foi o teor - cujas implicações procuramos esclarecer - da Ordinance de 18 de junho de 1349, subsistindo, ao lado dela, outros dois documentos que remontam à mesma oportunidade e que merecem uma atenção maior do que a que lhes tem sido dedicada. O primeiro deles, uma circular dirigida ao arcebispo de Winchester, mas na verdade constituindo um modelo de comunicação a ser dirigida aos demais bispos do reino, mostra que Eduardo III procurou obter o apôio do clero para conseguir sucesso na aplicação da Ordinance. Nela, solicita

(63) - BERESFORD,op. cit., pp. 177 sqq. [60]; VAN BATH, op . cit., pp. 164 sqq. [51]. Nesse periodo os senhores teriam feito valer seus direitos sobre suas terras, cercando-as e vedando a sua ocupação por camponeses.

(64). - RYMER, loc. cit. [5]; STATUTES..., loc. cit. [6]; PUTNAM, loc. cit. [152].

(65). - "... consilia brevia diriguntur singulis vicecomitibus per Angliam". Referências idênticas às da nota anterior. 
o momarca os bons ofícios do prelado para tornar público o diploma legal nas igrejas e demais locais de sua diocese e recomenda-lhe instruir os párocos, vigários e demais ministros sob sua jurisdição a predicar induzindo os seus paroquianos a trabalhar e aceitar as determinações da ordenação (66). A ascendência dos religiosos sobre o povo na época é suficientemente conhecida para que tal providência necessite comentários mais longos.

Em contra-partida, a recomendação seguinte de Eduardo III é extremamente sintomática das vicissitudes por que passava a Igreja após a Peste Negra. Pede o rei providências ao arcebispo para que os capelões estipendiários de sua diocese dem o exemplo, prestando os serviços religiosos sem exigir pagamentos exagerados, contentando-se com os habituais, sob pena de suspensão e interdição (67). Inicialmente, a circular revela que a valorização da mão-de-obra tinha atingido o próprio setor religioso, já que a pesada mortalidade entre os membros do clero valorizou o trabalho dos. sobreviventes. Inclusive, sabemos que, quando da aplicação da legislação em exame, constataram-se casos de processos contra sacerdotes, por abandono de seus postos (68). Por outro lado, o comportamento inconveniente do clero - e não é preciso muita imaginação para avaliar os abusos que muitos sacerdotes cometeram, pela simples leitura da presente recomendação do rei - justifica a tendência da historiografia inglesa a estabelecer uma relação entre a Peste Negra e o desenvolvimento de sentimentos anti-clericais e reformistas que culminaram com o movimento Lollard, que agravaram consideravelmente a tendência de muitos ingleses a ver na Igreja uma entidade hostil à Inglaterra e favorecedora dos interesses da França (69). Em contra-partida, sabemos que toda essa situação gerou um clima de inconformismo em amplos setores do clero inferior, que tendeu a identificar-se com os trabalhadores em seu repúdio à repressão de que eram objeto suas pretensões, e o resultado

(66). - "Et ideo vos rogamus quod premissa in singulis ecclesiis et locis aliis vostre diocese quibus expedire videritis publicari facere; mandantes rectoribus, vicariis ecclesiarum hujusmodi ministris et aliis subditis vostris, ut parochianos suos ad laborandum et ad tenendum ordinaciones predictas, sicut instans necessitas exigit, salutaribus monitis solicitent et inducant..." STATUTES, loc. cit. [6]; PUTNAM, pp. 11-12 (apênd.) [152].

(67). - "Vos eciam Capellanos Stipendiarios dicte vostre diocese, qui similiter jam sine excessivo nolunt dicitur servire salario, compescatis; et ad serviendo per consueto salario prout expedit, sub pena suspensionis et interdicti compellatis". STATUTES, loc. cit. [6]; PUTNAM, p. 12 (apêndice) [152] .

(68) . - B. H. PUTNAM, pp. 187 sqq. [152].

(69). - GASQUET, pp. 235 sqq. [122]; COULTON, Medieval Panorama, pp. 495 sqq. [118]; JESSOPP, op. cit., pp. 247 sqq. [126]. 
foi a participação de grande número de religiosos no levante geral de 1381 (70).

$\mathrm{O}$ outro documento que subsiste ao lado da Ordinance tem as características de uma ata do Conselho Real e consiste sobretudo num resumo das providências adotadas na ordenação - aliás, alí classificada como Statutum de Operariis - e sob esse ponto de vista não há qualquer interesse em nele nos determos, o que somente nos conduziria a repetições inúteis. Contudo, há nele dois pontos merecedores de relêvo: ele nos permite precisar o ano da promulgação da Ordinance e comprova que a Peste Negra apresentou consequências nefastas para a arrecadação fiscal, num momento em que a Inglaterra estava a braços com uma guerra dispendiosa.

Com relação ao primeiro ponto é indicado claramente o $23^{\circ}$ ano do reinado de Eduardo III como o da promulgação da Ordinance (71), que é muda a esse respeito, apenas indicando o dia e o mes, o que nos permite indicar com segurança o ano de 1349 como aquele em que se verificou tal ocorrência.

Muito mais interessante é a observação concernente às consequências fiscais atribuidas à exigência de remunerações exorbitantes que já levavam muitos contribuintes a se declararem, devido a elas, inaptos a quitarem sua parcela do dízimo e quínzimo (72). Ocorre que esses dois impostos representavam contribuições excepcionais, cuja incidência se verificava mediante autorização dos próprios contribuintes e em geral eram estabelecidos para fazer face às despesas com a guerra. No caso em pauta a concessão fora feita na primavera de 1348, às vésperas da eclosão da epidemia, portanto, e era válida por 3 anos (73).

A fim de aliviar os contribuintes o rei, assistido sempre por seu Conselho, decidia que sempre que fossem constatados recebimentos de importâncias superiores às permitidas como remuneração e não houvesse denunciante - e, por conseguinte, beneficiários de tais

(70). - PETIT-DUTAILLIS in STUBBS, pp. 867 sqq. [157a].

(71). - O texto inicia-se da seguinte forma: "Per quod dominus Rex xiiii die Junii anno regni sui vicesimo tercio, singulis Vice-comitibus Anglie per diversa breviia precepit..." STATUTES, T. 1, p. 309 [6]. E curioso observar que enquanto a Ordinance e a circular aos bispos omitem o ano, a presente ata se equivoca na indicação do dia, o que faz com que todos esses documentos deixem a desejar sob algum aspecto quanto à datação.

(72) . - "... Dominus Rex, ex populari questione accipiens ipsum populum propter huiusmodi excessiva stipendia, liberaciones et precia, que a servitoribus, operatoribus et artificibus coacto solvebantur, aliter deprimi sub decima et quinte-decima ipsum contingentes solvi non poterant, nisi aliud remedium provideretur..." STATUTES, loc. cit. [6].

(73). - PUTNAM, pp. 99 sqq. [152]. 
"excesses" - as mesmas reverteriam ao tesouro real e seriam deduzidas dos débitos das respectivas comunidades com relação ao dízimo e quínzimo (74). Um dos resultados de tal providência foi complicar notavelmente os problemas de jurisdição, visto que - ao lado dos magistrados locais aos quais incumbia zelar pelo cumprimento das disposições da Ordinance e dos juizes especiais encarregados de inspeciona-los - vemos os cobradores de dízimos com poderes para deter aqueles que se recusassem a devolver em dobro as importâncias superiores às permitidas que tivessem recebido (75). Sobre o resultado prático desta medida nada sabemos quanto ao primeiro triênio (1349-1352), mas tendo se verificado uma renovação da concessão das referidas taxas por mais 3 anos em 1352 e tendo chegado dados de sua cobrança até nós, verifica-se que a porcentagem dos "excesses" do total do dízimo e quínzimo recolhido montava a cerca de $6 \%$, podendo - consideradas certas lacunas da documentação - ter chegado a cerca de $10 \%(76)$.

Estes são os termos da legislação inglesa relativa à contenção dos exageros em matéria de salários e preços verificados em decorrência da Peste Negra e o que a caracteriza é a tendência a encarar essas anomalias como simples abusos da camada trabalhadora da população, desejosa de explorar os empregadores, prevalecendo-se de uma momentânea carência de mão-de-obra. As soluções preconizadas para resolver tais problemas se caracterizam pela simplicidade e, se nos permitem o emprego de uma expressão bem brasileira, se resumiriam

(74). - "... quod omnes et singuli operarii, servientes et artifices... pro serviciis et artificiis suis quam anno vicesimo, et aliis annis supradictis, solebant capere capientes, ad totam illam summam quam ultra receperint, cum aliis summis tam pro tempore tunc preterito quo stipendia, salaria, liberaciones et precia augmentata fuerit, tam pro tempore tunc futuro, assiderentur que tota illa summa ultra sic recepta singulis eorundem et colligetur ad opus regis, singularum villarum unde dicti artifices servitores et operarii fuerint, et in auxilium solucionis summarum ad quas eedem ville seu homines earum et decimam et quintedecimam tunc adhuc currentes fuerit assessi..." STATUTES, loc. cit. [6].

(75). - "... illis qui propter hoc servire rennuunt, vel summas per eos sic ultra receptas et super assessas solvere, et artificia sua et opera exercere, statim per taxatores et collectores decime et quintedecime predictarum vel eorum aliquem, in singulis villis ad premissa exequenda deputanda, vel per baillivos locorum seu constabularios villarum, cum de hoc eis constaret, arrestarentur et gaole comitterentur, in edem detinendo quosque ad serviendo securitatem postiterint, et solverint que sic ultra receperint..." STATUTES, loc. cit. [6].

(76). - Em 1352 o total do dízimo e quínzimo somou $114.767 £ 5 \mathrm{sh}$. e $2 \mathrm{~d}$. e o das penalidades $7.747 £ 14 \mathrm{sh}$. e $2 \mathrm{~d}$. Mas, deve-se considerar que tal desconto não foi uniformemente da mesma porcentagem, variando de local para local e tendo sido consideravel em certos casos. O assunto está magistral e minuciosamente estudado por B. H. PUTNAM, pp. 106 sqq [152]. 
na restauração "por decreto" do statu quo ante, mediante certos processos jurídicos-administrativos não destituidos de engenho, mas de uma duvidosa eficiência, pelo simples fato de contrariarem por completo as tendências da conjuntura. Todavia, isso não implica em considerá-los completamente inócuos, como foi voga durante muito tempo (77), visto que a obra de Putnam a que tanto temos recorrido nas notas comprova que houve uma mobilização de toda a justiça britânica, real e local, para forçar a sua aplicação. Os interessados no estudo do funcionamento da justiça inglesa a esse respeito devem se dirigir a esse livro, pois nos absteremos de penetrar nesse terreno - a não ser muito ocasionalmente e a título meramente ilustrativo - por duas razões: a primeira é a de que o problema se encontra muito bem estudado no trabalho icitado e a outra é a de que tal aspecto pouco interessa aos objetivos do nosso trabalho, que visa sobretudo localizar os sintomas de crise na legislação e interpreta-los.

Mesmo que não tivéssemos indicações concretas a respeito, tudo nos levaria a duvidar da eficácia de providências tão simplistas e rígidas para fazer face a uma situação caracterizada por uma grande fluidez. Todas as ameaças e penalidades seriam incpazes de preencher os claros abertos nas fileiras dos trabalhadores pela epidemia e a lei da oferta e da procura obedece a certos mecanismos que nenhuma legislação pode alterar por simples dispositivos repressivos. Mas, o fato é que nem sequer necessitamos nos entregar à tais suposições, pois dispomos de indícios bastante segurós da eficiência limitada de tais medidas, representados pelas frequentes reiterações - os enforcements - das mesmas pelas autoridades, o que seria desnecessário em caso de pleno sucesso. Os enforcements foram extremamente abuntes e caracterizados por um endurecimento crescente nas medidas punitivas adotadas, fato simultaneamente indicativo do insucesso dessa legislação e da crença de seus promotores de que ele se devia à insufíciência de energia em sua aplicação, valendo a pena examina-los visto que eles permitem melhor caracterizar a extensão da crise e contribuem para uma melhor compreensão da evolução inglesa posterior nos setores econômico e social.

As medidas subsequentes adotadas em relação à questão dos salários e preços o foram, a partir de 1351 , em reuniões do Parlamento, estando datadas das oitavas da purificação de Nossa Senhora e estão enfeixadas numa série assaz compósita de documentos, todos classificados como "estatutos", mas nem sempre com conexão com nossa te-

(77). - Esta foi a posição de Th. Rogers e, por mais que ele tenha sido contestado, até a publicação do livro de Putnam, não foi contraditado nesse pormenor. 
mática. O primeiro deles, por exemplo, interessa mais como subsídio para o estudo das consequências jurídicas da Peste Negra do que para o esclarecimento de suas repercussões econômicas e sociais: determina ele que as crianças nascidas fora do solo ingles, mas descendentes de pais ingleses, tenham direitos de herança idênticos aos das nascidas na Inglaterra, por analogia com a legislação anterior relativa aos filhos dos reis, considerados como príncipes ingleses, onde quer que nascessem (78). A necessidade de regulamentação da matéria resultou da conjunção da guerra com a França - provocando a multiplicação de nascimentos de filhos de nobres ingleses fora da Inglaterra - com as devastações da epidemia, fazendo proliferar os processos de herança. A epidemia é diretamente evocada e a necessidade de uma regulamentação desse tipo é sintomática quanto à extensão da mortalidade que ela provocou.

O documento seguinte é designado nos manuscritos como Statutum de Servientibus - ou, el língua vulgar, estatut d'artifices et servantz - e traduzido por Statute of Labourers em edições impressas, e nós o consideraremos como tal para não confundi-lo com a ordenação de 1349, que vimos de analisar, classificada, por sua vez, como Statutum de operariis. O documento de 1351 diferencia-se do anterior por ser mais minucioso quanto às suas determinações, alem de agravar por vezes as penalidades previstas na Ordinance de 1349, mas representa apenas um suplemento desta e não deve ser considerado como um substitutivo (79). Outra distinção a ser destacada diz respeito ao idioma utilizado, pois, ao contrário da Ordinance, ele está redigido em língua vulgar, no caso o franco-normando - devendo-se lembrar que $o$ inglês somente passou a ser utilizado em documentos oficiais a partir dos inicios do século XV (80) - o que indica que o diploma legal de 1351 estava destinado a uma mais ampla divulgação, visto ser o franco-normando, pelo menos na nobreza, mais difundido do que $o$ latim.

Na exposição de motivos faz-se um rápido resumo das disposições sobre os salários contidas na ordenação de 1349 e menciona-se o fato de que uma petição dos Comuns queixa-se de que os trabalhadores não as respeitavam, usando de malícia, para grande prejuizo dos grandes do reino do povo comum, o que levou o rei a recomendar ao Par-

(78). - STATUTES, T. 1, p. 310 [6].

(79). - B. H. PUTNAM, p. 2 [152].

(80). - SUGGETT, The Use of French in England... TRHS, 1946, passim [47]. 
lamento a elaboração do novo documento (81). Tal indicação revela que, apesar da menção expressa dos grandes do reino, as queixas partiam sobretudo dos Commons, provavelmente da pequena nobreza e médios proprietários, merecendo ainda destaque o fato de a epidemia continuar a ser responsabilizada pela falta de mão-de-obra e de se persistir na tendência a atribuir ao comportamento dos trabalhadores a razão principal das dificuldades. Nas determinações que se seguem, mais precisas do que as da Ordinance de 1349, continua-se a tomar por base o período 1344-1346 (20 ${ }^{\circ}$ ano do reinado de Eduardo III o 4 ou 5 anos anteriores a 1349).

Em relação aos carroceiros, charruadores com ou sem bois, pastores, porqueiros, deyes (82) e outros servidores análogos não se estabelece exatamente a remuneração mas apenas se atribui uma equivalência - nos casos de pagamento in natura - de 10 pence ao alqueire (bushel) de trigo, se estipula que, nas regiões em que o costume fosse o de pagar em espécie, ficasse ao critério do empregador a determinação da forma de remuneração e, finalmente, que os contratos deviam ser anuais e não por dia (83). De um lado verifica-se uma indubitavel parcialidade a favor dos empregadores, pois a estes ficava a decisão de pagar in natura ou em dinheiro. numa fase de flutuações consideráveis no curso dos produtos agrícolas, o que deixava os trabalhadores na situação de dever aceitar sem queixas ao serem remunerados em espécie quando os produtos agrícolas estavam em baixa e em

(81). - "Come nadgairs contra la malice de seruantz, queux furent preciouses et nient voillantz seruir apres la pestilence, sanz trop outrageouses lowers prendre, feut ordiné par nostre seigreur le Roi et par assent des prelatz, nobles et autres de son conseil... (segue resumo da ordenação de 1349). Et ia par tant que doné est entendre a nostre dit seignur le Roi en cest parlement, par la peticion de la commune, que les ditz servantz nient eiantz regard a la dite ordenance, mes a lour eses et singulers couetises, se retreent de seruir as grantz ou as outres sils neyent liueresons et lowers au duble ou treble de ceo quils soloient prendre le dit an vintisme et devant, a grant damage des grantz, et empouericement de touz ceux de la dite commune, dont il estroit prie par mesme la commune de remedié; par qoi en mesme le parlement... pur refreyndre la malice des ditz seruantz sont ordenés et establés les choses suzescriptz". STATUTES, T. 1, p. 311 [6]; PUTNAM, pp. 12-13 (apêndice) [152].

(82). - Confessamos não ter chegado a uma conclusão sobre que tipo de servidor poderia tratar-se. O significado mais razoavel talvez seja o de regador, de duie, termo que designava tanto um pequeno curso d'água quanto um cântaro.

(83). - "Que chescun charetter, caruer, chaceour des carues, bercher, porcher, deye et touz autres seruantz, preignent liueresons et lowers accustumes le dit an vintisme et quatre annz deuant; issint qen pays ou furment soleit estre doné, preignent pur le bussel $\mathrm{x} \mathrm{d}$. ou furment a la volunté le donur, tanques autrement soit ordeigne; et qils soient allowes de setuir par lan entier ou autres termes vsuels, et nemye par iounés...". STATUTES, loc. cit. [6]; B. H. PUTNAM, p. 13 (apểndice) [152]. 
dinheiro nas fases de alta e, de outro, o desejo de reprimir a mobilidade da mão-de-obra, estipulando contratos a longo termo. A este respeito, convem acentuar que os estudos de Putnam revelam que os processos mais numerosos concerniam exatamente os caso de trabalhadores que abandonavam seus postos antes de terminado o prazo de duração (84), juntamente com as exigências de remunerações superiores às permitidas.

Para outras categorias de trabalhadores agrícolas, cujos serviços se faziam necessários mais esporadicamente - cortadores de grama (fauchours des prez), segadores e debulhadores - são previstos salários diários (vide cifras no apêndice II), variáveis conforme o grau de necessidade. O único comentário a ser feito é de que já antes da epidemia tais salários se encontravam em alta e os autores do projeto teriam exatamente se fixado nos preços mais baixos dos anos anteriores (85). Todavia, outras recomendações merecem relevo. Por exemplo, em relação aos segadores é recomendado portar ostensivamente seus instrumentos nos locais de trabalho e de não alugar seus serviços privadamente e sim em lugares públicos (86), o que sugere que havia um mercado negro de mão-de-obra e que as autoridades tinham dificuldade em controla-lo. Por outro lado, em relação aos debulhadores ordena-se que os mesmos deviam, duas vezes por ano, fazer juramento junto às autoridades locais de permanecer nos seus locais de residência no inverno durante o verão, a menos que ficasse comprovado não haver serviço nesta última estação (87). O sentido dessa disposição - o de evitar que esses servidores viessem a faltar exatamente no momento das colheitas, em que a necessidade aguda da mão-de-obra acentuava as perspectivas de melhor remuneração, induzindo à transumância - é suficientemente claro para exigir comentários mais longos. Mas como os hábitos transumantes estavam profundamente arraigados em determinadas regiões - sobretudo por não haver uma necessidade acentuada de mão-de-obra agrícola por ocasião das colheitas,

(84) . - B. H. PUTNAM, pp. 181 sqq. [152].

(85). - "Moreover, in an excess of unwise economy, the Statute estimates the old rate at its lowest instead of its highest average - at 2-3 d. a day instead of at 3-4 d. . There would have been much more prospect of carrying out the scheme with success if something had been conceded to the labourer but he was offered only the worst possible bargain". Ch. OMAN, p. 7 [151]

(86). - "... et que tieux ouerours portent ouertement en lour meyns as villes marchantz lour instrumentz, et illoeques soient alowes en lieu commune et nemye priué". STATUTES, loc. cit. [6]; B. H. PUTNAM, loc. cit. [152].

(87). - "... et que mesmes les seruantz soient sermentez deux foitz par an deuant seigrurs, seneschals, baillifs et conestables de chescune ville, a ceste chose tenir e faire, et que nul de eux irra hors de la ville ou il demoert en yuer, pur seruir en estee, sil puisse auoir seruice en mesme la ville...". Referências idênticas às da nota anterior. 
por serem nelas as culturas pouco desenvolvidas - são excluidos da observância dessa prescrição os habitantes de Staford, Lancastre e Derby, bem como os de Craven e das marcas de Gales e Escócia, aos quais é permitido trabalhar em outros condados em agosto, conforme o faziam anteriormente (88).

Embora a redação seja um tanto imprecisa e dê a entender que esse juramento devia primordialmente ser exigido apenas dos debulhadores, estes constituiam um ramo secundário dos trabalhadores das colheitas para se justificasse a exigência duas vezes por ano de juramento e, sobretudo, a severidade das penas aos que se recusassem a ele, determinando-se que eles deveriam ser atados ao pelourinho por 3 dias ou encaminhados à prisão mais próxima, alí permanecendo até obedecer (89). Recomenda-se igualmente a erecção de pelourinhos em cada localidade até a festa de Pentecostes seguinte, o que indica que a desobediência às recomendações reais era tão generalizada que se julgava indispensavel a sistematização dos exemplos públicos, o que constitui um notório endurecimento em relação à Ordinance de 1349 .

Em relação ao importante setor dos trabalhadores de construção são estipulados tetos e a não ser a previsão de remunerações diárias mais baixas na estação fria, em que as jornadas de trabalho eram mais curtas, a serem fixadas por juizes especiais a serem designados e cujas atribuições são definidas mais adiante (90), nada mais se nos afigura merecedor de considerações mais alongadas. Passando aos artezãos, verifica-se que as autoridades julgavam suficiente o controle das corporações para manter os preços em níveis razoáveis, determinando-se apenas que os profissionais jurem diante das autoridades competentes a manutenção dos preços vigentes no período 1344-1346, sob pena de multas e prisão (91), mas o fato de tais trabalhadores terem tido um papel proeminente no movimento de 1381 indica que essa categoria tambem se encontrava sob forte pressão.

(88). - "... sauve que les gentz des countez de Stafford, Lancastre et Derby, et gentz de Crauen et de la marche de Gales et Descoce, et autres lieux puissent venir en temps Daust, de laborer en autres countés, et saluement returner come ils soloient faire auant ses heures...". STATUTES, T. 1, p. 312 [6]; PUTNAM, pp. 13-14 (apêndice) [152] .

(89) . - "... et que ceux que refusent de faire tiel serement ou perfourner ceo qils cunt iurés, ou empris, soient mys en ceppes par les ditz seignurs, seneschaux, baillifs et conestables des villes, par trois iours ou pluis, ou mandez a la prochaine gaole, a demorer illoeques tanques ils se voillent iusticer...". STATUTES, loc. cit. [6]; PUTNAM, p. 14 (apênd.) [152].

(90). - Os salários mais altos verificavam-se entre a Páscoa e a festa de São Miguel (29 de setembro), devendo as autoridades locais determinar salários mais baixos para o restante do ano. Mesmas referências da nota anterior. 
Os itens seguintes do documento não vão ńos deter longamente, visto relevarem mais da esfera jurídico-constitucional do que da econômico-social, referindo-se à aplicação das normas então estabelecidas. Já quando o texto tratava da estipulação dos salários diários de inverno dos trabalhadores de construção encontramos referências a juizes especiais, a serem nomeados pelo rei para zelar pela apiicação da lei e a importância a eles atribuida é tal que poderia nos tentar a ver nas autoridades locais meros executores de suas ordens, o que, porem, constituiria um exagero. Na verdade, esses juizes eram sobretudo fiscais e deveriam instalar tribunal 4 vezes por ano, embora pudessem faze-lo a título excepcional, se necessário: nos dias da festa da Anunciação (25 de março); de Santa Margarida (20 de julho), de São Miguel (29 de setembro) e de São Nicolau (25 de dezembro). A eles cabia pronunciar sentença contra aqueles que fossem detidos pelas autoridades locais (senescais, baillifs, constables, etc.), a quem continuava adstrita a maior parte da responsabilidade na aplicação da lei. Somente os juizes especiais, porem, tinham poderes para convocar testemunhas sob custódia em suas investigações (92) e tomar outras medidas de exceção. Todavia, somente a partir de dezembro de 1352, quase dois anos depois da promulgação do Statute é que tais nomeações se efetivaram, ficando até lá suas funções de fiscalização entregues aos keepers of the Peace e a separação de funções destes e dos justices of labourers persistiu até 1359, quando estes tenderam a desaparecer em detrimento dos primeiros. Uma vez transformados em justices of peace, os keepers of peace acabaram por concentrar em suas mãos as suas atribuições e as dos justices of labourers a partir de 1361, consagrando-se tal situação em 1368 (93).

O destino das punições financeiras ainda conttribuiu para complicar mais o já não muito simples problema de jurisdição, pois às autoridades locais, keepers of peace e justices of labourers vieram somar-se os coletores de dízimos já que cabia à Coroa, como já vimos, as importâncias pagas a mais, cuja caracterização não se devesse a de-

(91). - "... et que... (segue enumeração dos ofícios) soient sermentez deuant les dites iustices de faire et vser leur artes e offices en manere come ils fesoient le dit an vintisme et en temps deuant, sanz les refuser par cause de ceste ordinance; et si nul des ditz seruantz, laborers, oeuerours, ou artificers apres tiel serment fait viegne encontre celle ordinance, soit puni par fin, ranceon, et emprisonement, selonc la discrecion des dites justices". STATUTES, loc. cit. [6]; PUTNAM, loc. cit. [152] .

(92) . - "... et d'oier et terminer et mettre la chose en execucion par Exigend apres le primer Capias si mestier soit...". STATUTES, T. 1, p. 313 [6]; PUTNAM, p. 15 (apêndice) [152].

(93). - PUTNAM, pp. 9 sqq. [152] e "The Transformation..." passim [153]. 
núncia - seja de uma das partes, seja de um particular - devendo ser deduzidas do dízimo e quínzimo devidos pelas respectivas comunidades onde tivesse se verificado o delito (94). Igualmente destinadas ao alívio do dízimo e quínzimo das respectivas comunidades deviam ser as importâncias eventualmente recolhidas a título de emolumentos (fees), sequência de prisão ou qualquer outro pretexto por sheriffs, constables, baillifs, carcereiros, e clérigos escrivães ou quaisquer outros mebros das cortes locais, com o que se procurava prevenir abusos da parte destes. No caso das importâncias recolhidas superaram o quínzimo devido por alguma cidade, que o excedente revertesse em favor das cidades mais pobres das imediações (95).

Essas medidas relevam claramente de preocupações fiscais e já fizemos alusão ao índice que seus resultados podiam apresentar (vide acima, página 94), mas a apropriação indébita de tais recursos devia assumir grandes proporções, pois o rei demonstra não ter confiança nem mesmo nos próprios coletores de dízimo e quínzimo, ao recomendar aos justices of labourers que, ao transferir para aqueles importâncias dessa natureza, o fizessem empregando o sistema da endenture, ou seja a redação em duas cópias do recibo numa mesma folha de pergaminho ou papel, com rubricas na linha divisória cortadas de maneira irregular, a fim de facilitar a identificação das partes. Em caso de não recolhimento ao tesouro real de tais importâncias, o coletor ficava sujeito a processo.

Já próximo do fim, estabelece o Statute que o julgamento de trabalhadores que abandonassem seus condados, desobedecendo os dispositivos da legislação em exame, e que fossem aprisionados por isso, deveria ser feito pelos juizes especiais, sendo que no caso em que isso ocorresse no intervalo entre as visitas deles à aludida localidade, os trânsfugas deveriam ficar aprisionados até a sessão de julgamentos

(94). - "... et en cas que nul voudra suir pur tiel excesse reavoir, adonqes soit levé des ditz servantz, overours, laborers et artificers et liveré as coillours de la quinzisme, en allegeance des villes ou tiel excesse fut pris". STATUTES, loc. cit. [6]; PUTNAM, loc. cit. [152].

(95). - "... et en cas que l'excesse trové en une ville passe la quantité de la quinzisme de meisme la ville, soit le remenant de tiel excesse levé, e paié par les ditz coillours a les plus proscheines villes povres, en eide de lour quinzisme, par avisement des ditz justices". STATUTES, loc. cit. [6]; PUTNAM, p. 16 (apêndice) [6]. 
seguinte (96). Em tais casos, as autoridades do condado ao qual pertencesse o fugitivo podiam exigir a sua detenção junto às daquele onde este tivesse se refugiado, exigindo sua extradição, mas o julgamento ficava sempre a cargo dos juizes especiais. Esta recomendação demonstra que se atribuia particular gravidade às migrações de mão-de-obra, temendo talvez o legislador que em determinadas localidades as autoridades locais demonstrassem benevolência, encorajando a multiplicação de casos dessa natureza (97). Mas, ao mesmo tempo, a recomendação de que aqueles que fossem aprisionados em tais circunstâncias ficassem detidos até a visitação do justice of labourers autoriza dúvidas quanto à uma migração intensa, pois isso implicaria em manter na prisão por meses um grande número de trabalhadores, o que não parece muito verossímel. Não há dúvida de que o legislador pode ter subestimado as proporções dos movimentos de população ou que, sem confessa-lo, tenha contado com um número consideravel de casos em que as devidas providências deixariam de ser tomadas, por discreção das partes interessadas ou por negligência das autoridades judiciárias, mas tais ressalvas não devem impedir-nos de ver no documento um convite a não exagerar as proporções das migrações internas decorrentes das perturbações econômicas e sociais resultantes da Peste Negra, ao menos no que diz respeito às deslocações a longa distância (98).

No mais, o documento, já no seu fecho, repete as mesmas recomendações da Ordinance de 1349 - inclusive a suspensão de franquias - e por isso não vamos nos deter a respeito. Num balanço geral, verificamos que o estatuto pouco acrescentou de realmente novo em relação ao documento de 1349 , sendo a sua principal característica ser menos genérico e esclarecer aspectos das disposições de seu antecessor. Durante algum tempo não tivemos maiores iniciativas no setor, a não ser, a partir de 1353 a nomeação dos juizes especiais para os

(96). - "... et si nul des ditz laborers, artificers ou servantz senfue dun countee tanques en autre, par cause de ceste ordinance, que les viscontes des countés ou tiels futiues serront trouez les facent prendre, au mandement des iustices des countés dont ils senfuerent, et le mesnent a la chief gaole de meisme cel counté, illoeques a demurer tanques a la proscheine session des meismes les iustices, et que les ditz viscontz returnent tielx mandements deuant meismes les iustices a lour proscheines sessions...". STATUTES, loc. cit. [6]; PUTNAM, p. 17 (apêndice) [152].

(97). - O excelente estudo de B. H. Putnam é curiosamente omisso quanto à aplicação deste artigo e fazemos tal suposição por analogia com casos comprovados em relação a outros reinos europeus, sobretudo Portugal e Castela .

(98). - PERROY, art. cit. p. 181 [99], a nosso ver exagerando, exprime dúvidas categóricas a respeito: "On ne voit pas bien ce que signifiaient ces dernières stipulations. La crainte d'une fuite généralisée des vilains et d'une mobilité de la main-d'oeuvre était vaine". 
problemas de trabalho (99), mas verificou-se uma iniciativa ligeiramente mais importante em 1357. Nessa oportunidade, tendo já cessado o segundo triênio de cobrança de dízimo e quínzimo (1352-1354) o monarca, certamente sob a pressão dos grandes do reino, ordenava que as quantias resultantes da cobrança de penalidades pecuniárias levantadas em terras de senhores cujas franquias compreendiam a percepção de multas e taxas, revertesse em favor dos mesmos. Em contra-partida, ele obrigava os referidos senhores a contribuirem para o pagamento dos salários dos justices of labourers em proporção com as importâncias que tenham recebido (100). Assim, verificamos que se a legislação sobre os salários e preços não constituiu um grande sucesso na conjuração dos problemas que a motivaram, ao menos suas punições parecem ter constituido uma fonte razoavel de receita para os poderes públicos, a justificar polêmicas a respeito de jurisdição entre o rei e a nobreza.

Nos fins de 1360 iniciou-se uma nova visita geral da Peste Negra na Inglaterra, o que representa o fim do nosso ciclo legislativo. Tal epidemia, ao contrário da de 1348, que teve na Inglaterra, se não o seu ponto terminal, pelo menos uma das regiōes tardiamente afetadas, parece ter tido o seu ponto de partida no norte, atingindo a Itália apenas em 1362 (101). Apelidada, como já indicamos (vide capítulo dois), mortalité des enfauntz, ela não parece ter atingido profundamente a população em idade laboriosa, mas de qualquer forma deve ter provocado um forte impacto psicológico e provocado novas tensões sociais. Ademais, coincidiu ela com o fim de um ciclo no que se refere à Guerra dos Cem Anos, pois foi precedida de poucos meses pelo tratado de Bretigny ( 8 de maio de 1360), iniciando-se uma das longas tréguas que interromperam o secular conflito. Assim, não é surpreendente verificarmos que por ocasião da preparação de uma reunião do Parlamento, no final do $34^{\circ}$ ano de reinado de Eduardo III, às vésperas da festa de Conversão de São Paulo (portanto em janeiro de 1361, já que o monarca fôra coroado em 29 de janeiro de 1327), importantes decisões tenham sido tomadas em relação a problemas econômicos e sociais. Examina-las com a mesma minúcia com

(99). - PUTNAM, p. 17 [152].

(100). - " "... Acordé est et assentu, que les Seignours des fraunchises, qi ont fins, issues et amerciementz par point de chartre ou. en autre manere, eient desore enavant les dites, fins, issues et amerciementz des laborers, que a eux appartiegnent de droit, tant come la Justicerie des laborers dure. Issint totes voies que les ditz Seignours facent contribucion a paiement des feez de tieux Justices des laborers, solone lafferant des profitz qils enprendront". STATUTES, T. 1, p. 350 [6].

(101). - El. CARPENTIER, Une ville devant la peste..., p. 209 [117]. 
que tratamos dos documentos consecutivos à grande epidemia de 1348 representaria uma digressão que preferimos evitar, mas não nos parece despropositado referi-las rapidamente, pois nos permitirão melhor antever os desenvolvimentos posteriores do processo desencadeado pela primeira aparição da Peste Negra .

A paz com a França parece ter tido efeitos negativos sobre a estabilidade social do reino, pois já na primeira providência se ordena a formação de comissões especiais destinadas a coibir um incremento desmesurado do banditismo. A conexão do fenômeno com a paz com a França transparece na determinação que tais comissões investiguem scbre os que tinham se entregado ao banditismo nas partes de alem-mar (isto é, na França) e que, ao regressar, tenham se recusado ao trabalho, a fim de po-los na prisão (102). Assim, a marginalidade que já tinha sofrido um incremento desde a Peste Negra, encontrava-se bastante agravada. Se esta medida apresenta uma ligação um tanto probiemática com a Peste Negra de 1348, certos corretivos da legislação sobre salários e preços já são muito mais significativos a esse respeito.

Ficou então estabelecido que o Statute of Labourers devia ser mantido em todos os pontos exceto em relação às penalidades pecuniárias, ficando os trabalhadores delas isentos, com a contra-partida de um agravamento das demais formas de punição (103). A razão da providência não apresenta mistérios muito profundos, visto que as penalidades pecuniárias davam margem a abusos por parte dos tribunais - o que podia ser tolerado em época de guerra, quando o fruto das punições ia para os cofres reais, mas não agora com a paz - e somente ocasionalmente podiam ser pagas pelo contraventor, sendo, portanto, igualmente ineficientes.

Com relação ao agravamento das demais formas de punição, as autoridades respectivas ficavam autorizadas a deterem por até 15 dias os trabalhadores faltosos a fim de tentar obter a sua adesão aos termos do estatuto para então envia-los à prisão mais próxima onde ficariam até jurarem obediência aos mesmos, proibindo-se, por outro lado,

(102). - "... et auxint de eux enformer et denquere de touz ccux qi ont esté pilours et robeours es parties de dela, et sont ore revenuz et vont vagantz, et ne voillent travailler come ils soleient avant ces hours; et de prendre et arester touz ceux qils porront trover par enditement, ou par suspecion et les mettre en prisone...". STATUTES, T. 1, p. 364 [6].

(103): - "Acordé est en ceste present parlement que lestatut des laborers auncienement fait estoise en touz pointz, forspris la penance pecuniere que desore est acordé que les laborers ne soient pas punitz par fins et raunceons; et est assentuz que le dit estatut soit efforcé en punissement des laborers en forme que sensuyt...".STATUTES, T. 1, p. 366 [6]. 
as autoridades de receber dos detidos qualquer importância a qualquer ttulo, sob pena de indenização de 5 libras à parte prejudicada e 10 ao rei (104). Depois de enumerar as categorias de trabalhadores a que tal legislação se aplicava, proibe-se qualquer forma de remuneração aos pedreiros e carpinteiros, que não o salário diário, com o que se procurava, provavelmente, evitar gratificações e formas suplementares de remuneração que pudessem representar uma burla da lei. No capítulo dos salários a única inovação é a equiparação entre carpinteiros e pedreiros, que passou a ser indistintamente de 4 para os mestres e de 3 ou 2 pence para os demais, conforme suas habilitações (esses eram os salários dos pedreiros no estatuto de 1351, enquanto os carpinteiros recebiam apenas 3 e 2 pence, respectivamente) (105).

$\mathrm{Na}$ Ordinance de 1349 salientamos um item que representava uma restrição às iniciativas de associações profissionais espontânea para a obtenção de melhor remuneração (vide acima, páginas $86-87$ ). Em relação aos carpinteiros e pedreiros o presente documento é muito mais explícito, proibindo categoricamente todas as alianças e combinações, bem como congregações, capítulos, ordenações e juramentos feitos ou a fazer entre eles (106). O fato de no presente documento ao contrário do que ocorria com a Ordinance de 1349 - se referir apenas aos pedreiros e carpinteiros e num tom muito mais enérgico de condenação, autoriza conjecturas a respeito. E provavel que tais iniciativas fossem sobretudo frequentes nessas categorias profissionais, caracterizadas por uma grande mobilidade - o que dificultava a sua organização em corporações conformes ao modelo jurídico em voga - estimulando os encontros informais e os acordos secretos. Aliás, a segunda metade do século XIV é a época em que surgem os primeiros indícios seguros da constituição de sociedades maçonicas, derivadas - como o seu próprio nome indica - da associação livre (isto é, não corporativa) de pedreiros, o que faria da presente providência uma das primeiras repressões sofridas por tais organizações, dentre as muitas que elas viriam a receber da parte dos poderes públicos através dos séculos (107).

Mas, talvez a medida mais significativa seja a extrema severidade reservada à mão-de-obra itinerante, sendo que o trabalhador loca-

(104). - Idem, loc. cit.

(105). - Idem, pp. 366-367.

(106). - "... et que totes alliances et covignes des Maceons et Carpenters, et congregacions, chapitres, ordinances et serementz entre eux faites ou. affaires, soient desore anientiz et anullez de tout...". STATUTES, T. 1, p. $367[6]$.

(107). - TH. ROGERS, Histoire..., p. 28 [155], faz uma alusão nesse sentido. 
lizado fora de seu condado devia jurar obedecer os termos do "Statute". Uma vez voltando ao seu condado e verificando-se nova fuga devia ser declarado fora da lei e quando aprisionado, somente poderia ser libetado quando a parte denunciante estivesse segura de sua regeneração, sendo que, independentemente da soltura, podia ter a testa marcada com um ferro em brasa representando a letra " $F$ ", símbolo de falsidade (108). E verdade que tal pena somente deveria ser aplicada depois da festa de São Miguel seguinte (29 de setembro), cerca de 8 meses depois e somente poderia ser pronunciada sentença pelos juizes reais, sendo ameaçados de multa pesada os magistrados locais que a colocassem prática.

Por fim, determina-se que sempre que um senhor localizasse em prisão um servidor seu, este deveria ser incontinenti solto pela autoridade que o detivesse, sob pena de multa de $10 £$ ao rei e indenização de $5 £$ à parte queixosa. Assim, nesta oportunidade o reforço dos laços de dependência não foi inteiramente esquecido pelo legislador.

Assim, vemos que se a legislação não teve sucesso quanto aos seus objetivos - e dificilmente poderia te-lo, de tal forma contrariava o processo em marcha - ela não foi inteiramente inoperante e, inclusive, passou a representar, mercê da insistência na sua aplicação, um fator de agravamento das dificuldades do período. Fica por ela evidente o abalo sofrido pelas relações entre senhores e dependentes, patrões e empregados, e mesmo produtores e consumidores, em consequência da falta de mão-de-obra resultante da grande mortalidade. A oposição entre a camada possuidora da população e o setor laborioso já trasparece nitidamente nas entrelinhas da legislação. Tal oposição ainda tendeu a se acentuar à medida que novas manifestações epidêmicas se verificavam e mais rígida se tornava a legislação, acabando por se verificar a ocorrência de formas violentas na manifestação do descontentamento do setor menos favorecido da população. Se a Peste Negra não foi o agente por excelência no desencadeamento dạ crise

(108). - "Item des laborers et artificers qi salloignent hors de lour services en autre ville ou en autre Countée, que la partie eit sa suite devant justices, et que le viscont lui preigne au premier jour come est contenu en lestatut, sil soit trové, e face de lui execucion come dessus est dit. Et sil retourne qil nest mie trové eit lexigende au premier jour, et se suy tanque il soit utlaie, et apres la utlagarie soit brief de mesmes les justices mandé a quconque visconte Dengleterre que la partie vodra suir de lui prendre et lui mander au visconte du Countée ou il est utlae, et quant il serra illoeqes mesné, eit illoeqes la prison tanque il se voet justicer et eit fait gree a la partie. Et nientmeins par sa fauxine soit ars en le frount duné fer fait et fourmé au manere de la lettre F, en signe de Fauxine si la partie grevé le vodra suyer... Idem, loc. cit. 
- as guerras com a França e a Escócia e suas sequelas econômico-financeiras tem uma grande significação nesse sentido, e nós não nos furtamos em insistir a respeito - mas não há dúvida de que a legislação econômica e social dela decorrente contribuiu poderosamente para o desencadeamento da revolta dos trabalhadores de 1381 e para uma deterioração geral das estruturas da Inglaterra no fim da Idade Média .

(Continua) . 